\title{
Pemberdayaan Pusat Kesehatan Pesantren (POSKESTREN) Untuk Meningkatkan Perilaku Hidup Bersih Dan Sehat
}

\author{
Erwin Nur Rif'ah, S.Sos., MA. Ph.D \\ Fakultas Kesehatan Masyarakat \\ erwinnur.fkm@unej.ac.id
}

\begin{abstract}
Abstrak
Pondok pesantren dikenal sebagai suatu lembaga pendidikan Islam tertua di Indonesia. Banyaknya jumlah pesantren di Jember, serta besarnya jumlah santri pada tiap pesantren menjadikan lembaga ini memiliki kontribusi yang besar dalam pembangunan. Berdasarkan hasil penelitian sebelumya ditemukan bahwa masalah yang sering dihadapi pesantren adalah rendahnya kesadaran berperilaku hidup bersih dan sehat. Akibatnya banyak santri yang mengalami sakit dan tinggi penularan penyakit infeksi di kalangan santri. Edukasi dasar-dasar PHBS kepada para santri diharapkan dapat meningkatkan nilai pengetahuan santri terkait urgensi dari implmentasi PHBS. Pembentukan dan pelatihan Kader Santri Sehat juga diharapkan mampu menjadi salah satu upaya meningkatkan lifeskill hidup sehat bagi santri untuk hidup sehat secara mandiri sekaligus menjaga kestabilan kualitas lingkungan sehat di pesantren yang akan dibentuk. Inisiasi dan pendampingan pembentukan Poskestren di kedua pesantren juga dilakukan guna menciptakan suatu sistem manajemen kesehatan terpadu dan terstruktur di lingkungan pondok pesantren. Sehingga harapan pengasuh pondok pesanten untuk meningkatkan mutu bekal keterampilan santri dapat tercapai. Solusi dalam peningkatan pengetahuan terkait PHBS di kedua pondok pesantren akan dilaksanakan melalui beberapa metode, antara lain: 1) Pembekalan atau alih teknologi; yaitu penyadaran dengan memberikan informasi dan keterampilan pada penghuni pondok pesantren tentang dasar-dasar, manfaat, dan urgensi PHBS komunitas di lingkungan pondok pesantren; 2) Pendampingan; yaitu melalui pendampingan terhadap pondok pesantren dalam membentuk Poskestren; 3) Pelatihan manajemen dan pembentukan Kader Santri Sehat; yaitu memberikan pengetahuan tentang pengelolaan dan pembangunan relasi kerja untuk Poskestren, serta melakukan pelatihan bagi Kader Santri Sehat sebagai investasi keberlanjutan program Poskestren yang telah didirikan. Partisipasi mitra dilakukan mulai tahap persiapan hingga pengelolaan Poskestren yang terbentuk. Partisipasi mitra dievaluasi pada setiap kegiatan, sehingga diharapkan pada saat akhir kegiatan, keberlanjutan program dapat tetap berjalan.
\end{abstract}

\section{Kata kunci: Pondok Pesantren, Sangria, Poskestren, PHBS.}

\begin{abstract}
Islamic boarding school (pondok pesantren) is known as the oldest Islamic educational institution in Indonesia. The large number of pesantren in Jember and the large number of santri in each pesantren make this institution have a large contribution in development. Based on the result of previous studies, the problem often faced by pesantren is the low awareness of behaving clean and healthy life. In response, the students are getting illness and high transmission of infectious diseases among them.
\end{abstract}


Education of the basics PHBS for students is expected to increase the value of student's knowledge related on the implementation's unrgency of PHBS. The formation and training of Healthy Santri Cadres are also expected to be one of the efforts to improve healthy life's skill for students to live healthy independently while to maintain quality of stability in healthy environment in pesantren which to be formed. Initiation and assistance in the formation of Poskestren in both pesantren is implemented in order to create integrated and structured health management system in the boarding school environment. So that, the expectation of islamic boarding school caretaker is to improve the quality of the student's provision skill can be achieved. Solution in increasing knowledge related to PHBS in both boarding schools will be implemented through several methods, including: 1) Provisioning or transfering technology; namely awareness by providing information and skills to the boarding school dwellers about the basic, benefit and urgency of PHBS community in the boarding school environment; 2) Assistance; namely through accompeniment to Islamic boarding schools in forming Poskestren; 3) Management training and formation of Healthy Santri Cadres; namely providing knowledge about the management and development of work relationships for Poskestren, and conducting training for Healthy Santri Cadres as an investment in the sustainability of the Poskestren program that has been established. Partner participation is carried out from the preparatory stage to the management of the formed Poskestren. Partner participation is evaluated in each activity, so it is expected that at the end of the activity, the sustainability of program can continue.

Keywords: Islamic Boarding School, Sangria, Poskestren, PHBS. 


\section{PENDAHULUAN}

Jember dikenal sebagai kota pesantren karena di kabupaten Jember terdapat ratusan pesantren yang tersebar baik di kota maupun di desa. Pondok pesantren dikenal sebagai lembaga pendidikan Islam tertua di Indonesia. Keberadaan pondok pesantren memiliki nilai strategis dalam membina insan yang memiliki kualitas iman, ilmu dan amal (Nasir, 2005). Banyaknya jumlah pesantren di Jember, serta besarnya jumlah santri pada tiap pesantren menjadikan lembaga ini memiliki kontribusi yang besar dalam pembangunan. Pesantren akan memiliki kontribusi yang lebih optimal, jika pesantren mampu menghasilkan SDM yang handal baik dari aspek keilmuan maupun Kesehatan, sebagaimana peribahasa menyebutkan 'Di dalam badan yang sehat terdapat jiwa yang Kuat'.

Ikhwanudin (2013) dalam penelitiannya menemukan bahwa respon santri terhadap perilaku kesehatan masih kurang dipandang dari sudut pandang medis modern, karena pesantren memiliki kultur yang berbeda dengan masyarakat diluar pesantren. Hal ini terlihat dari pertama, dalam memelihara kesehatan, santri masih mempertahankan diri dari penyakit dan menjaga kesehatan masih dengan cara yang sederhana. Kedua, dalam usaha memanfaatkan sistem kesehatan, santri mengacu pada pengetahuan kesehatan yang santri pahami. Ketiga, perilaku kesehatan lingkungan santri dipengaruhi erat struktur dan nilai-nilai budaya serta nilai-nilai religi yang ada dipesantren. Keempat, usaha rasionalisasi PHBS (Perilaku Hidup Bersih Dan Sehat), dengan menyesuaikan dengan nilai-nilai kultural dan religi di pesantren guna meningkatkan derajat kesehatan santri.

Selanjutnya Kuspriyanto, (2013) menemukan insiden scabies di pondok pesantren yang cukup tinggi yaitu $54,9 \%$. Hal in disebabkan karena kondisi sanitasi dasar lingkungan pondok pesantren yang masih rendah dan tidak memadai. Kondisi tersebut menimbulkan masalah kesehatan diantarnya adalah terdapat kejadian scabies di pondok pesantren dan juga wabah kutu rambut. Selain itu mudahnya santri tertular sakit.

Berdasarkan hasil penelitian tersebut di atas dapat disimpulkan bahwa masalah yang sering dihadapi pesantren terkait kesehatan adalah buruknya higienitas dan sanitasi di pesantren serta rendahnya kesadaran kesehatan dan perilaku sehat para santri. Oleh karena itu perlu dilakukan pembinaan secara terus menerus dengan melibatkan para santri dan warga pesantren.

Salah satu pesantren di Jember yang mulai berkembang adalah pondok pesantren Ar-Roudhoh yang didirikan oleh K.H Hisyam Balya pada awal tahun 1991. Lokasi pondok pesantren Ar-Roudhoh terletak di Desa Baratan Kecamatan Patrang. Jarak pondok pesantren dengan Universitas Jember $\pm 3 \mathrm{~km}$. Hampir seluruh santri berasal dari kalangan miskin dan yatim atau piatu. Usia santri mulai dari 5 tahun sampai 25 tahun. Mereka berpendidikan PAUD sampai Perguruan Tinggi. Bagi santri yang sudah masuk perguruan Tinggi biasanya diberi tanggung jawab untuk menjadi pengurus atau ustadz/ustadzah. Setiap tahun minat masyarakat terhadap pondok pesantren semakin meningkat. Hal ini dikarenakan pengasuh pesantren cukup peka terhadap kebutuhan santri baik dari segi pendidikan agama, akhlak dan pendidikan formal lainnya. Selain itu, bagi santri miskin atau yatim dan/atau piatu, pesantren menyediakan beasiswa. Oleh karena itu, para santri banyak yang berasal dari luar kota seperti Banyuwangi, Bondowoso, Situbondo, Jombang, Cirebon bahkan luar Jawa. 
Selain karena menyediakan beasiswa bagi para santrinya, dan juga karena lokasinya yang relatif strategis di dekat kota, Pesantren Ar-Roudhoh juga mampu menciptakan santri-santri yang ber-akhlaqul karimah sehingga menjadikan Pondok Pesantren Ar-Roudhoh terus berkembang. Manajemen pondok pesantren bersifat sentralistik dengan artian seluruh kebijakan dan kegiatan dikontrol oleh seorang pengasuh. Pengurus serta

Ustadz/ustadzah hanya membantu dan penjalankan program yang sudah ditetapkan oleh pengasuh. Para santri di Pondok pesantren Ar-Roudhoh, selain belajar pendidikan agama di pesantren dan belajar di sekolah-sekolah umum sesuai dengan usia dan tingkat pendidikannya, mereka juga belajar berorganisasi dan mengelola kegiatan yang ada di pesantren dan lingkungan sekitar pesantren.

Perkembangan serta kemajuan pesantren tersebut sayangnya kurang didukung dengan sarana dan prasarana yang memadai. Jumlah kamar yang tidak sesuai dengan jumlah santri, serta kesadaran penghuni pesantren akan kesehatan masih di bawah standar Perilaku Hidup Bersih dan Sehat. Kenyataan ini yang mendorong tim pengabdian masyarakat dari Universitas Jember turun langsung ke lapang. Selama kegiatan observasi, tim pengabdian semakin merasa tergerak untuk melakukan perubahan terhadap lingkungan pesantren dan sekitarnya. Kebutuhan lifeskill hidup sehat inilah yang melandasi munculnya keinginan kerjasama dengan Perguruan Tinggi. Pengasuh pesantren sangat mengharapkan adanya transfer ipteks untuk meningkatkan kemandirian dan perilaku hidup bersih dan sehat para santri agar kelak setelah lulus dari pesantren mereka memiliki ketrampilan hidup, selain ilmu agama, sebagai bekal mereka hidup sehat di masyarakat.

Berdasarkan analisa situasi terhadap pesantren Arrodhoh, maka bisa disimpulkan bahwa persoalan yang dihadapi oleh pesantren adalah:

1. Pengasuh dan pengurus pesantren Ar-Roudhoh telah berupaya menyediakan sarana dan memberikan pengetahuan pentingnya PHBS, tetapi para santri masih mengalami kesulitan dalam mengimplemetasikan nilai-nilai kesehatan karena kurangnya pengetahuan tentang dasar-dasar kesehatan dan PHBS sehingga kesadaran akan berperilaku hidup bersih dan sehat sangat rendah.

2. Pesantren mengalami kesulitan dalam penyediaan tenaga penyuluh dan Pembina kesehatan.

3. Pesantren belum mampu berkoordinasi dengan pihak-pihak terkait di luar pondok karena keterbatasan pengetahuan dan jaringan.

4. Pesantren belum memiliki Poskestren.

5. Tingginya angka kejadian penyakit infeksi kulit dan sakit perut.

6. Mudah tersebarnya/tertularnya suatu penyakit yang diderita satu santri kepada santri lain.

7. Terlambatnya penanganan jika santri sakit. 

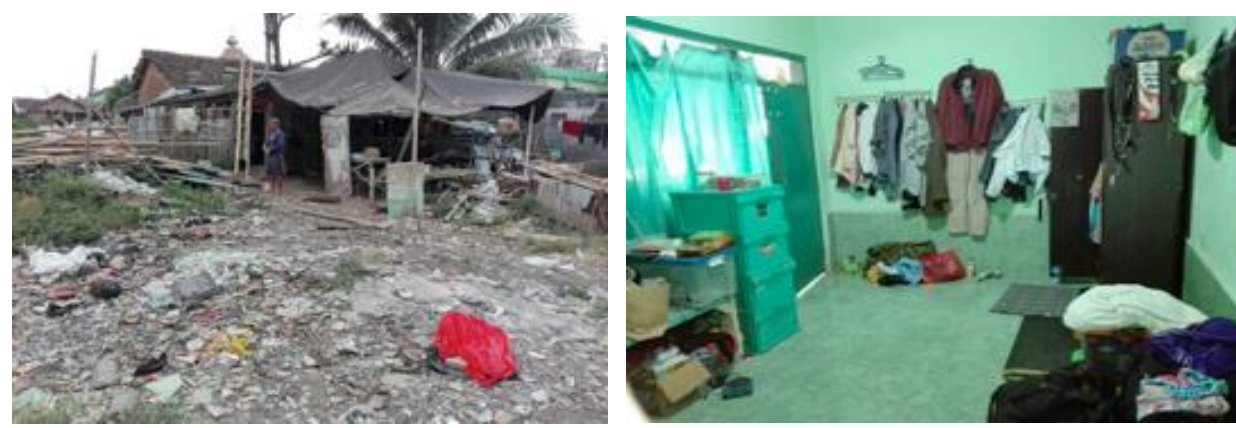

Gambar Kondisi Kamar di Pesantren yang tidak bersih, serta Kondisi tempat pembuangan sampah yang tidak tertutup berpotensi untuk penyebaran penyakit

\section{METODE PELAKSANAAN}

Dari analisis situasi dan permasalahan yang terjadi pada mitra maka solusi yang dapat kami tawarkan adalah diadakannya program edukasi PHBS, inisiasi pembentukan Poskestren, pelatihan dan pendampingan kader Santri Sehat untuk meningkatkan kualitas kesehatan di lingkungan pesantren Ar-Roudhoh Metode yang kami laksanakan terdiri dari 4 tahap yaitu tahap persiapan, tahap pelaksanaan, tahap evaluasi, dan tahap pelaporan hasil kegiatan.

\section{Tahap Persiapan}

Adapun tahap persiapan sebelum dilaksanakan kegiatan adalah :

1. Melakukan survey pendauluan ke Pondok Pesantren untuk melakukanpersiapan kegiatan. Pada momen ini sekaligus dilakukan pendataan ulang santri yang nantinya akan dilatih dan menjadi kader kesehatan

2. Melakukan persiapan seperti persiapan materi, banner, obat, alat-alat kesehatan dan poster promosi kesehatan.

3. Melakukan koordinasi dengan pengurus pondok pesantren Ar-Roudhoh dan persetujuan kesediaan bekerjasama.

4. Perekrutan tim kerja

Merekrut tim kerja dari mahasiswa Fakultas Kesehatan Masyarakat Universitas Jember untuk ikut serta dalam kegiatan pengabdian ini

5. Menyiapkan perlengkapan penunjang

6. Melakukan penyusunan materi, serta perlengkapan untuk menunjang proses edukasi tentang PHBS dan rangkaian kegiatan pengabdian yang telah direncanakan

\section{Tahap Pelaksanaan}

Pendekatan yang dilakukan oleh pengusul kepada mitra merupakan pendekatan yang berbasis penggerakan peran masyarakat pesantren, yaitu segala upaya fasilitasi yang bersifat persuasif dan tidak memerintah, yang bertujuan untuk meningkatkan pengetahuan, sikap dan perilaku masyarakat dalam menemukan, merncanakan dan memecahkan masalah dengan menggunakan sumber daya/ potensi yang mereka miliki termasuk partisipasi dan dukungan tokoh masyarakat. Format solusi yang ditawarkan adalah dalam bentuk kegiatan pelatihan dan pendampingan. Pelatihan dilakukan secara klasikal dengan metode 
ceramah, diskusi dan praktek, dengan menggunakan alat bantu viewer, alat peraga dan contoh-contoh yang relevan dengan materi yang akan diberikan.

Penggerakan peran masyarakat yang dilkakukan pada program ini diwujudkan dengan melakukan pendekatan kepada pengasuh pesantren untuk memperoleh dukungan dalam pembinaan PHBS di komunitas. Selain itu kegiatan ini juga memberdayakan warga pesantren untuk melaksanakan PHBS melalui penyuluhan perorangan oleh kader santri sehat maupun penyuluhan kelompok. Pengembangan kegiatan-kegiatan yang mendukung terwujudnya komunitas ber-PHBS.

Metode yang digunakan untuk menyelesaikan masalah kesehatan di pesantren ini adalah metode partisipatoris. Artinya Tim dari Universitas Jember (UNEJ) akan terjun langsung melakukan penyuluhan / sosialisasi, pelatihan penanganan kesehatan dan PHBS kepada para santri. Tahapan pelaksanaannya sebagai berikut:

1. Melakukan sosialisasi program pelatihan pembinaan poskestren. Proses ini akan menjaring berapa santri yang akan dijadikan kader kesehatan pesantren dan mengikuti pembinaan dan pelatihan poskestren dan PHBS. Dalam tahap ini, juga akan dibentuk kelompok-kelompok kecil minat santri: tim medis terlatih (tim kreatif), tim administrasi, dan tim humas.

2. Menyiapkan alat dan bahan yang dibutuhkan. Pondok pesantren telah memiliki kotak obat yang kondisinya masih baik tetapi perlu mendapat tambahan dan diisi dengan obat-obatan. Selain kotak obat dan obat-obatan juga dibutuhkan stetoskop dan tensimeter, senter, dsb.

3. Mengadakan penyuluhan dan pelatihan tentang poskestren dan PHBS

4. Praktek pengobatan dasar dan PHBS;

5. Mensosialisasikan Poskestren dan PHBS kepada semua santri

\section{Tahap Evaluasi}

Tahap evaluasi dibagi menjadi 3 tahap yaitu tahap awal, tahap proses dan tahap akhir.

a. Evaluasi Tahap Awal

Dilihat dari respon dan penerimaan sasaran terhadap rencana kegiatan pengabdian terkait edukasi PHBS dan inisiasi pendirian Poskestren di pondok pesantren Ar-Roudhoh dan Al-Khodijah.

b. Evaluasi Proses

1. Keaktifan para santri saat mengikuti kegiatan penyuluhan

2. Respon para santri (feedback) yang diberikan terhadap pertanyaan yang diajukan selama penyampaian materi

3. Para santri dapat memahami informasi mengenai PHBS dan pengobatan dasar

c. Evaluasi Hasil

1. Adanya perningkatan pengetahuan dari santri terkait PHBS, pengobatan dasar, dan Poskestren

2. Adanya pemahaman dari pengurus pondok pesantren tentang urgensi pembentukan Poskestren 


\section{PEMBAHASAN DAN HASIL}

Program ini merupakan kerja sama antara Tim Pengusul dengan pengelola pesantren Ar-Roudhoh sebagai mitra. Tim Pengusul bertindak sebagai pelatih (trainer), fasilitator dan pendamping, sedangkan pengelola serta santri pondok pesantren Ar-Roudhoh sebagai peserta pelatihan dan edukasi.

Jumlah peserta untuk program pelatihan dan pendampingan ini sebanyak 25 santri. Program pelatihan dilakukan melalui kegiatan di dalam dan di luar kelas, sedangkan program pendampingan dilakukan secara langsung berupa praktek di lapangan. Pelatih berperan sebagai pemberi materi dan pembimbing saat diskusi dan praktek kelas. Penyampaian materi dengan metode ceramah dilakukan di dalam kelas yang dilanjutkan dengan diskusi dan praktek kelas yang dilakukan langsung oleh peserta pelatihan dengan dibimbing oleh pelatih.

Adapun target luaran berdasarkan solusi yang ditawarkan antara lain: a) Meningkatnya pengetahuan santri terkait dasar-dasar PHBS; b) Santri mampu menjadi kader kesehatan sekaligus penyuluh kesehatan di lingkungan pesantren (peer learning); c) Pesantren mampu berkoordinasi dengan pihak-pihak terkait di luar pondok dalam rangka inisiasi pendirian Poskestren; d) Adanya inisiasi pendirian Poskestren; e) Adanya pemahaman pihak pengurus pondok pesantren tentang pembentukan Poskestren; f) Menurunnya angka kejadian penyakit infeksi kulit dan sakit perut serta penularan penyakit antar santri; g) Adanya manajemen pertolongan pertama dan perawatan terpadu untuk santri yang sakit; h) Adanya media promosi kesehatan yang mendukung terlaksananya PHBS di lingkungan sekolah, seperti : booklet, poster, dan buku saku

Perilaku Hidup Bersih dan Sehat merupakan semua perilaku yang dilakukan atas kesadaran sehingga anggota keluarga atau keluarga dapat menolong dirinya sendiri di bidang kesehatan dan berperan aktif dalam kegiatan-kegiatan kesehatan dimasyarakat. PHBS di komunitas adalah upaya untuk memperdayakan anggota komunikasi agar tahu, mau dan mampu melaksanakan perilaku hidup bersih dan sehat serta berperan aktif dalam gerakan kesehatan di masyarakat. Manfaat komunitas pesantren ber-PHBS antara lain: a) Setiap anggota warga pesantren menjadi sehat dan tidak mudah sakit; b) Santri tumbuh sehat dan cerdas; c) Pengeluaran biaya operasional pesantren untuk pengobatan dapat dialihkan untuk tujuan lain. Salah satunya memenuhi gizi santri.

Manfaat dengan berperilaku hidup bersih dan sehat selain dirasakan oleh komunitas pesantren juga bisa dirasakan oleh masyarakat sekitar pesantren, yaitu antara lain: a) Masyarakat mampu mengupayakan lingkungan sehat; b) Masyarakat mampu mencegah dan menanggulangi masalah -masalah kesehatan; c) Masyarakat memanfaatkan pelayanan kesehatan yang ada; d) Masyarakat mampu mengembangkan Upaya Kesehatan Bersumber Masyarakat (UKBM).

Departemen Kesehatan (2001) telah menetapkan 16 indikator PHBS dalam komunitas,yaitu : 1) Gosok gigi sebelum tidur; 2) Olahraga teratur; 3) Memiliki saluran pembuangan air limbah; 4) Ventilasi rumah baik; 5) Kepadatan penghuni rumah (kesesuaian luas lantai dengan jumlah penghuni); 6) Lantai rumah bukan tanah; 7) Persalinan ditolong oleh tenaga kesehatan; 8) Imunisasi dan penimbangan balita; 9) Memiliki jamban sehat; 10) Memiliki akses air bersih; 11) Penangan sampah; 12) Kebersihan kuku; 13) Gizi keluarga; 14) Tidak merokok 
dan penyalahgunaan NAPZA; 15) Memiliki informasi AIDS/PMS; 16) Memiliki jaminan pemeliharaan kesehatan.

Selain edukasi terkait PHBS, kegiatan ini juga melakukan Penyuluhan dan Pelatihan Kader Kesehatan Pesantren. Kader Santri Sehat memiliki peran, antar lain:

a. Melakukan pendataan santri yang ada di pesantren dengan menggunakan Kartu Pencatatan PHBS pada buku kader.

b. Melakukan pendekatan kepada pengasuh pesantren untuk memperoleh dukungan dalam pembinaan PHBS di komunitas.

c. Sosialisasi PHBS di pesantren dan sekitarnya melalui door to door.

d. Memberdayakan warga pesantren untuk melaksanakan PHBS melalui penyuluhan perorangan, penyuluhan kelompok dan pergerakan masyarakat.

e. Mengembangkan kegiatan-kegiatan yang mendukung terwujudnya komunitas ber-PHBS.

f. Memantau kemajuan pencapaian komunitas ber-PHBS di wilayahnya setiap tahun melalui pencatatan PHBS di komunitas pesantren.

Setelah terbentuk kader santri sehat diharapkan inisiasi pendirian poskestren bisa dilakukan. Selama ini Pondok Pesantren telah memiliki beberapa ruang yang bisa dikembangkan menjadi pos kesehatan pesantren yang lebih baik, sesuai dengan standar poskestren. Selain itu poskestren bisa menjadi tempat kaderisasi kader kesehatan serta sebagai tempat penanganan awal bagi santri yang sakit sehingga dapat mengurangi terjadinya penyakit-penyakit akibat buruknya PHBS dan mengurangi menularnya penyakit infeksi di kalangan santri.

\section{Kesimpulan}

\section{KESIMPULAN DAN SARAN}

Dari hasil pembahasan implementasi pengabdian dosen dengan judul Pemberdayaan Pusat Kesehatan Pesantren (Poskestren) untuk Meningkatkan Perilaku Hidup Bersih dan Sehat, maka dapat ditarik kesimpulan sebagai berikut : a. Pengetahuan dan kesadaran santri terkait perilaku hidup bersih dan sehat rendah.

b. Untuk meningkatkan pengetahuan dan memberdayakan warga di pondok pesantren Ar-Roudhoh dilakukan melalui pendekatan yang berbasis penggerakan masyarakat.

c. Peningkatan pengetahuan dikemas dalam kegiatan klasikal berupa ceramah dan praktik oleh tim.

d. Kegiatan edukasi tentang PHBS, pembentukan kader santri sehat dan inisiasi pendirian Poskestren di pondok pesantren Ar-Roudhoh dilanjutkan dengan usaha pendampingan dalam upaya menjaga keberlanjutan dan perluasan mitra kerja 
Saran

Mengingat banyaknya jumlah pesantren serta besarnya jumlah santri pada tiap pesantren, maka kegiatan pengabdian sejenis dirasa penting. Kegiatan pengabdian ini juga mendapat respon positif dari pihak pesantren dalam aspek kebermanfaatan serta kemasan kegiatan yang telah dilakukan. Oleh karena itu pengusul berharap pihak Universitas Jember dapat memfasilitasi kegiatan-kegiatan sejenis pada pondok pesantren lainnya di Kabupaten Jember dengan melibatkan peran serta dari stake holder yang bersangkutan. Sehingga upaya peningkatan derajat kesehatan secara paripurna di Kabupaten Jember dapat terlaksana secara sistematis dan berkelanjutan khususnya di lingkungan pondok pesantren.

\section{DAFTAR PUSTAKA}

Anonim. 2012. Jember Dalam Angka 2012, BPS dan BAPPEDA Kab. Jember, Jember.

Departemen Kesehatan RI. 2002. Panduan Manajemen PHBS menuju Kabupaten/Kota Sehat. Jakarta: Depkes RI.

Efendi, F. 2009. Keperawatan Kesehatan Komunitas: Teori dan Praktek dalam Keperawatan. Jakarta: Salemba Medika.

Haryono, Akhmad. 2009. Perilaku Kewirausahaan Lulusan Pesantren Salaf (Sebagai Upaya Mendesain Kurikulum Pesantren Salaf Berbasis Budaya dan Berorientasi Kewirausahaan). Lembaga Penelitian. Universitas Jember.

Ikhwanudin, Alim. 2013. Perilaku Kesehatan Santri : (Studi Deskriptif Perilaku Pemeliharaan Kesehatan, Pencarian dan Penggunaan Sistem Kesehatan Serta Perilaku Kesehatan Lingkungan Di Pondok Pesantren Assalafi Al Fithrah,Surabaya)Jurnal Social dan Politik,

http://journal. unair.ac.id /filerPDF/ JURNAL\%
2520PERILAKU\%2520KESEHATAN\%2520SANTRI.docxU diakses tanggal 6 April 2015.

Khumayra, Z.H., Sulisno, M. 2012. Perbedaan Pengetahuan Dan Sikap Perilaku Hidup Bersih Dan Sehat (Phbs) Antara Santri Putra Dan Santri Putri, Jurnal Nursing studies, Vol. 1, No 1 2012. Hal 197 - 204, http://ejournal-s1.undip.ac.id/index.php/jnursing.

Kuspriyanto,2013. Pengaruh Sanitasi Lingkungan Dan Perilaku Sehat Santri Terhadap Kejadian Skabies Di Pondok Pesantren Kabupaten Pasuruan Jawa Timur http://ejournal.unesa.ac.id/jurnal/jurnal_geografi/abstrak/5935/pengaruhsanitasi-lingkungan-dan-perilaku-sehat-santri-terhadap-kejadian-skabiesdi-pondok-pesantren-kabupaten-pasuruan-jawa-timur.

Mallongi, Anwar; Puspitasari, Ayu; Ikhtiar, Muhammad; Arman; Arsunan, A. A., 2018. Analysis of Risk on the Incidence of Scabies Personal Hygiene in Boarding School Darul Arqam Gombara Makassar, Indian Journal of 
Public Health Research \& Development. Apr 2018, Vol. 9 Issue 4, p 227-231.5p.

https://web.b.ebscohost.com/abstract?direct=true \&profile=ehost \&scope= $\underline{\text { site } \& \text { authtype }=\text { crawler } \& \text { jrnl }=09760245 \& A N=129662040 \& h=b 0 f l Y T V p}$ cdDT8cwehrz3gYAcvHWq3T31A5yeUHIIG7i3LdwlUBgRUd4A6vM2 LTIOIXyUOvTRzPS8I\%2bNyR1\%2bsHg\%3d\%3d\&crl=c\&resultNs=Ad minWebAuth\&resultLocal=ErrCrlNotAuth\&crlhashurl=login. aspx\%3fdi rect $\% 3$ dtrue $\% 26$ profile $\% 3$ dehost $\% 26$ scope $\% 3$ dsite $\% 26$ authtype $\% 3$ dcra wler\%26jrnl\%3d09760245\%26AN\%3d129662040.

Nasruddin Syam , Abd. Gafur, Wardiah Hamzah. 2018. PkM Pengembangan Pos Kesehatan Pesantren (Poskestren) Di Yayasan Wakaf Umi Pesantren Wihdatul Ulum Desa Bontokassi, Kec. Parangloe, Kab. Gowa Tahun 2017, Jurnal Balireso Vol. 3, No. 1, Januari 2018, http://jurnal.umi.ac.id/index.php/lpmd/article/viewFile/65/24.

Notoatmodjo, 2010.. Soekidjo. Ilmu Perilaku Kesehatan. Jakarta: Rineka Cipta

Notoatmodjo. 2003. Pendidikan dan Perilaku Kesehatan. Jakarta : Rineka Cipta

Prasetyawati, Arsita. 2011. Ilmu Kesehatan Masyarakat untuk kebidanan holistik. Nuha Medika, Yogyakarta.

Richard, M. Simon. 2009. Gender Differencess in Knowledge and Attitude Toward Biotechnology. Public understanding of science 2010. Diakses melalui http://prq.sagepub.com.

Sanusi, Uci. 2012. "Pendidikan Kemandirian di Pondok Pesantren (Studi Mengenai Realitas Kemandirian Santri di Pondok Pesantren Al-Istiqlal Cianjur dan Pondok Pesantren Bahrul Ulum di Tasikmakaya". Artikel di Jurnal Pendidikan Agama Islam - Ta'lim Vol. 10, No. 2. 2012.

Tantut Susantoa; Lantin Sulistyorini; Emi Wuri Wuryaningsih; Syahroni Bahtiar. 2016. School health promotion: A cross-sectional studyon Clean and Healthy Living Program Behavior(CHLB) among Islamic Boarding Schools inIndonesi. International Journal of Nursing Sciences. Volume 3, Issue 3, September 2016, Pages 291-298, https://www.sciencedirect.com/science/article/pii/S2352013216300254.

Wawan, A. dan M. Dewi, 2010. Teori dan Pengukuran Pengetahuan, Sikap, dan Perilaku Manusia. Yogyakarta: Nuha Medika. 